\title{
EFEKTIVITAS APLIKASI MOBILE LEARNING ROLE PLAY GAMES (RPG) MAKER MV UNTUK MENINGKATKAN KEMAMPUAN BERPIKIR KRITIS
}

\author{
Abdur Rasyid ${ }^{1}$, Aden Arif Gaffar ${ }^{2}$, Widi Utari \\ Prodi Pendidikan Biologi, Universitas Majalengka \\ Jl. Raya K.H Abdul Halim No.103, Majalengka 45418, Indonesia \\ Email: abdurrasyid87@unma.ac.id ${ }^{1)}$, adenarif@unma.ac.id ${ }^{2)}$
}

Doi: https://doi.org/10.31943/mangiferaeduv4i2.47

Received: 06 Desember 2019 Accepted: 29 Januari 2020 Published: 31 Januari 2020

Citasi: Rasyid, A., Gaffar A,A., \& Utari, W. (2020). Efektvitas Aplikasi Mobile Learing

Role Play Games (RPG). Jurnal Mangifera Edu, 4 (2), 107-115

\begin{abstract}
Student learning activities that are less conducive, passive in asking questions and answering questions from problems raised by teachers, difficult to express ideas or ideas of problem solving and the learning process provided, and have not been oriented to develop students' critical thinking skills.The purpose of this study is to determine the feasibility, find out the increase in students' critical thinking skills, and to find out students' responses to the application of RPG maker MV based mobile learning applications in the learning ecosystem. The research method used is QuasiExperimental, the design used in this study is Quasi-Experimental Design with Randomized Control-Group Pretest-Postest. The data obtained in this study consisted of qualitative data, namely the results of observations of student activities during learning and student questionnaire responses to the application of mobile learning applications based on RPG maker MV, and quantitative data namely the results of students' critical thinking abilities. The results showed (1) the implementation of the RPG maker MV based mobile learning application has moderate criteria, (2) the application of the RPG maker MV based mobile learning application can improve students 'critical thinking skills, (3) students' responses to the use of RPG maker based learning mobile applications $M V$ in ecosystem learning has very good criteria
\end{abstract}

Keywords: Critical Thinking, Mobile Learning, Role Play Games (RPG), Ecosistem.

\section{ABSTRAK}

Aktivitas belajar siswa yang kurang kondusif, pasif dalam mengajukan pertanyaan maupun menjawab pertanyaan dari permasalahan yang diajukan guru, sulit mengemukakan ide ataupun gagasan penyelesaian masalah dan proses pembelajaran yang diberikan, serta belum berorientasi untuk mengembangkan kemampuan berpikir kritis siswa. Tujuan dari penelitian ini adalah untuk mengetahui keterlaksanaan, peningkatan kemampuan berpikir kritis, serta respon siswa terhadap penerapan aplikasi mobile learning berbasis RPG maker MV pada pembelajaran ekosistem. Metode penelitian yang digunakan adalah Quasi-Experimental, desain yang digunakan dalam penelitian ini adalah Quasi-Experimental Design dengan Randomized control-Group Pretest-Postest. Data yang diperoleh pada penelitian ini terdiri dari data kualitatif yaitu hasil observasi aktivitas siswa pada saat pembelajaran dan angket respon siswa terhadap penerapan aplikasi mobile learning 
berbasis RPG maker $M V$, dan data kuantitatif yaitu tes hasil kemampuan berpikir kritis siswa. Hasil penelitian menunjukan (1) keterlaksanaan penerapan aplikasi mobile learning berbasis RPG maker MV memilki kriteria sedang, (2) penerapan aplikasi mobile learning berbasis RPG maker MV dapat meningkatkan kemampuan berpikir kritis siswa, (3) respon siswa terhadap penggunaan aplikasi mobile learning berbasis RPG maker MV dalam pembelajaran ekosistem memiliki kriteria sangat baik.

Kata Kunci: Berpikir Kritis, Mobile Learning, Role Play Games (RPG), Ekosistem.

\section{PENDAHULUAN}

Perkembangan teknologi telah mondorong munculnya inovasi dalam pembelajaran dengan adanya media mobile learning. Mobile Learning adalah salah satu alternatif dalam pembelajaran dapat digunakan kapan saja dan dimana saja (Aripin, 2018). Penggunaan mobile learning sebagai media pembelajaran dapat menjadi salah satu media yang tepat bagi siswa dalam belajar di sekolah sehingga mudah mencapai tujuan pembelajaran dan meningkatkan antusis siswa (Alfiana dan Nurcahyo, 2018). Faktanya hasil observasi yang dilakukan di SMA Negeri 1 Majalengka melalui wawancara dengan guru biologi dan pengamatan langsung dalam proses pembelajaran, menunjukkan aktivitas belajar siswa yang kurang kondusif, pasif dalam mengajukan pertanyaan maupun menjawab pertanyaan dari permasalahan yang diajukan guru, sulit mengemukakan ide ataupun gagasan penyelesaian masalah dan proses pembelajaran yang diberikan, dan belum berorientasi untuk mengembangkan kemampuan berpikir kritis siswa.

Berpikir kritis merupakan kemampuan siswa dalam menentukan penilaian yang cermat dalam membuat keputusan dan menyelesaikan masalah (Zubaidah et al, 2018). Berpikir kritis digambarkan sebagai kemampuan menggabungkan konsep-konsep untuk memecahkan masalah (Hack \& Helwa, 2014). Kemampuan berpikir kritis dapat dilatih melalui analisis masalah, membuat keputusan, berusaha memahami sesuatu, dan menemukan jawaban untuk masalah (Safitri et al, 2018). Proses-proses tersebut dapat diperoleh dalam pembelajaran dengan bantuan media mobile learning.

Mobile learning dapat meningkatkan aktivitas siswa pada proses pembelajaran (Arindra et al, 2018). Menurut Hermawan et al (2017) ada banyak manfaat dengan menggunakan media ini seperti penghematan biaya, mengurangi jarak dan waktu, mendukung panjang pembelajaran jarak, dan mengurangi penggunaan kertas. Salah satu media yang dikembangkan penelitian ini memanfaatkan ponsel sebagai media pembelajaran berbasis Role Play Game (RPG) maker MV dengan ciri khas spesifikasi 
software 2D yang bisa digunakan tanpa keterampilan tertentu untuk menjalankannya (Sarrab dan Elgamel, 2013).

Penelitian dan pengembangan pembelajaran menggunakan game mobile learning berbasis RPG telah banyak dilakukan dan menunujukkan dampak yang positif terhadap hasil belajar (Ciampa, 2018). Tujuan dari penelitian ini adalah untuk mengetahui keterlaksanaan penerapan aplikasi mobile learning berbasis RPG maker MV, mengetahui peningkatan kemampuan berpikir kritis siswa, serta mengetahui respon siswa terhadap penggunaan aplikasi mobile learning berbasis RPG maker MV dalam pembelajaran ekosistem.

\section{METODOLOGI PENELITIAN}

Penelitian ini menggunakan pendekatan kualitatif dan kuantitatif dengan metode eksperimen. Permasalahan yang diangkat pada penelitian ini adalah permasalahan asosiatif yaitu suatu pernyataan yang bersifat menghubungkan dua variabel atau lebih. Hubungan yang terjadi adalah hubungan kausal yaitu hubungan sebab akibat, ada variabel independen (yang memepengaruhi) dan variabel dependen (yang dipengaruhi). Metode penelitian yang digunakan adalah Quasi-Experimental, desain yang digunakan dalam penelitian ini adalah Quasy-Experimental Design dengan Randomized control-Group Pretest-Postest. Alur penelitian terdiri dari tahap studi literasi, studi lapangan, perumsan masalah, validasi soal, pretest, pelaksanaan pembelajaran dengan diterapkannya aplikasi mobile learning berbasis RPG maker MV dan observasi aktivitas belajar, posttest, analisis data, hasil penelitian, dan kesimpulan (Cresswell, 2014).

Penelitian ini dilaksanakan di kelas X SMA N 1 Majalengka pada semester genap Tahun Pelajaran 2018/2019. Sampel dalam penelitian ini diambil secara acak (Cluster random sampling) sebanyak 2 kelas dengan jumlah 80 siswa. Satu kelas digunakan sebagai kelas eksperimen yaitu pembelajaran biologi menggunakan aplikasi mobile learning berbasis RPG maker MV, sedangkan satu kelas yang lainnya digunakan sebagai kelas kontrol yaitu pembelajaran biologi dengan menggunakan media charta. Instrumen yang digunakan dalam penelitian ini adalah lembar obeservasi, tes, dan angket respon. Data yang diperoleh pada penelitian ini terdiri dari data kualitatif yaitu hasil observasi aktivitas siswa pada saat pembelajaran dan angket respon siswa terhadap penerapan aplikasi mobile learning berbasis RPG maker MV, dan data kuantitatif yaitu tes hasil kemampuan berpikir kritis siswa. Data kualitatif dianalisis menggunakan format analisis konsep, dan analisis 
deskriptif menggunakan rubrik, sedangkan data kuantitatif dianalisis menggunakan statistik inferensi untuk menguji hipotesis (Scepanovic, 2015).

\section{HASIL DAN PEMBAHASAN}

Hasil penelitian berupa keterlaksanaan dan efektivitas penerapan aplikasi mobile learning berbasis RPG maker MV dalam pembelajaran Ekosistem, peningkatan kemampuan berpikir kritis siswa, dan respon siswa terhadap penggunaan aplikasi mobile learning berbasis RPG maker MV dalam pembelajaran Ekosistem. Keterlaksanaan proses pembelajaran di kelas eksperimen maupun kontrol sama-sama menggunakan metode reciprocal learning, diskusi, dan tanya jawab, tetapi yang membedakan adalah pada kelas eksperimen menggunakan aplikasi mobile learning berbasis RPG maker MV sedangkan kelas kontrol menggunakan media charta.

Keterlaksanaan penggunaan aplikasi mobile learning berbasis RPG maker MV di ukur dengan menggunakan instrumen observasi baik di kelas eksperimen maupun kelas kontrol. Keterlaksanaan tersebut dilihat dari aktivitas dan interaktif siswa dalam pembelajaran. Hasilnya keterlaksanaan aplikasi mobile learning berbasis RPG maker MV pada kelas eksperimen lebih baik daripada keterlaksanaan penggunaan media charta pada kelas kontrol. Penggunaan aplikasi mobile learning berbasis RPG maker MV sebagai media belajar mandiri dan interaktif membuat siswa lebih mudah dalam memahami materi. Penelitian ini senada dengan penelitian terdahulu bahwa aplikasi mobile learning berbasis RPG maker MV adalah sebuah program multimedia dan animasi untuk berkreasi membuat aplikasi-aplikasi unik, animasi-animasi interaktif pada halaman web, film animasi kartun, presentasi bisnis maupun kegiatan belajar mengajar (Faturahman et al, 2018).

Kemampuan berpikir kritis juga dilihat melalui tes yang dilakukan sebelum pembelajaran (pretes) dan setelah pembelajaran (postes). Data pretes dan postes selanjutnya diolah menjadi data gain. Uji N-Gain dipergunakan untuk mengetahui peningkatan efektivitas setelah pembelajaran dengan menggunakan aplikasi mobile learning berbasis RPG maker MV pada kelas eksperimen dibandingkan dengan kelas kontrol, seperti pada Tabel 1. 


\section{Tabel 1. Descriptive Statistics N-Gain}

\begin{tabular}{cccccc}
\hline Kelas & Mean & Variance & $\begin{array}{c}\text { Std. } \\
\text { Deviation }\end{array}$ & Minimum & Maximum \\
\hline Eksperimen & 61.86 & 97.08 & 9.86 & 40.00 & 75.00 \\
Kontrol & 35.67 & 153.13 & 1.237 & 20.00 & 60.00 \\
\hline
\end{tabular}

Berdasarkan tabel 1 menunjukkan bahwa nilai rata-rata N-Gain score untuk kelas eksperimen (aplikasi mobile learning berbasis RPG maker MV pada pembelajaran ekosistem) yaitu sebesar 61,86 termasuk dalam kategori cukup efektif, dengan nilai $\mathrm{N}$ Gain score minimal 40,00\% dan maksimal 75,00\%. Sedangkan rata-rata N-Gain score kelas kontrol (metode konvensional) yaitu sebesar 35,67 termasuk dalam kategori tidak efektif, dengan nilai N-Gain score minimal 20,00\% dan maksimal $60.00 \%$. Penulis dapat menyimpulkan bahwa penggunaan aplikasi mobile learning berbasis RPG maker MV pada pembelajaran ekosistem efektif dalam meningkatkan nilai siswa.

Pembelajaran pada materi ekosistem dengan menggunakan aplikasi mobile learning membantu siswa menyimpan informasi dalam ingatan jangka panjang, dan penggunaan animasi interaktif lebih efektif daripada animasi statis selama proses pembelajaran. Hal ini juga dapat diperkuat oleh Yusuf dan Afolabi (2010) yang menyatakan bahwa siswa yang diberi perlakuan pembelajaran menggunakan pembelajaran berbantuan komputer, baik secara individu maupun kelompok menunjukkan aktivitas belajar yang lebih baik daripada siswa yang tidak diberi perlakuan pembelajaran berbantuan komputer atau kelas dengan sistem pembelajaran konvensional. Hal senada juga diungkapkan oleh Weay dan Masood (2015) bahwa penggunaan multimedia dapat meningkatkan kemampuan penalaran dan berpikir kritis mahasiswa. Pembelajaran dengan multimedia interaktif juga dapat meningkatkan prestasi mahasiswa (Leow \& Neo, 2014)

Kemampuan berpikir kritis siswa juga dianalisis pada tiap indikator. Pada indikator memberikan penjelasan sederhana memiliki rata-rata nilai 76,6\% dengan kriterian baik, aspek indikator membangun keterampilan dasar memiliki skor 74,2\% dengan kategori cukup, aspek indikator menyimpulkan memiliki skor 74,61\% dengan kategori cukup, aspek indikator memberikan penjelasan lanjut memiliki skor 75,66\% dengan kategori baik, dan aspek indikator mengatur strategi dan taktik memiliki skor 74,3\% dengan kategori cukup. Sedangkan pada kelas control semua aspek indikator kemampuan berpikir kritis siswa memiliki skor 52\% dengan kategori kurang. Hal ini berarti bahwa kemampuan berpikir kritis pada kelas yang menggunakan mobile learning lebih baik pada setiap aspek indikator dibandingkan dengan kelas yang menggunakan media charta. 
Peningkatan kemampuan berpikir kritis siswa pada kelas yang menggunakan aplikasi mobile learning berbasis RPG maker MV yang lebih baik dapat terjadi karena aplikasi tersebut memiliki konten yang lengkap yang dapat memenuhi kebutuhan materi ekosistem seperti video, game, dan animasi proses saling ketergantungan mahluk hidup. Hal ini membuat siswa terampil mengkonseptualisasi, menerapkan, menganalisis, mensintesis, dan mengevaluasi informasi yang dikumpulkan dari tayangan aplikasi mobile learning berbasis RPG maker MV tersebut. Sebagaimana pendapat Hermawan et al (2017), menyatakan bahwa penggunakan aplikasi mobile learning berbasis RPG maker efektif dalam meningkatkan semangat belajar dan keterampilan berpikir kritis siswa. Adapun gambar tayangan animasi pembelajaran dan game dapat dilihat pada Gambar 1.

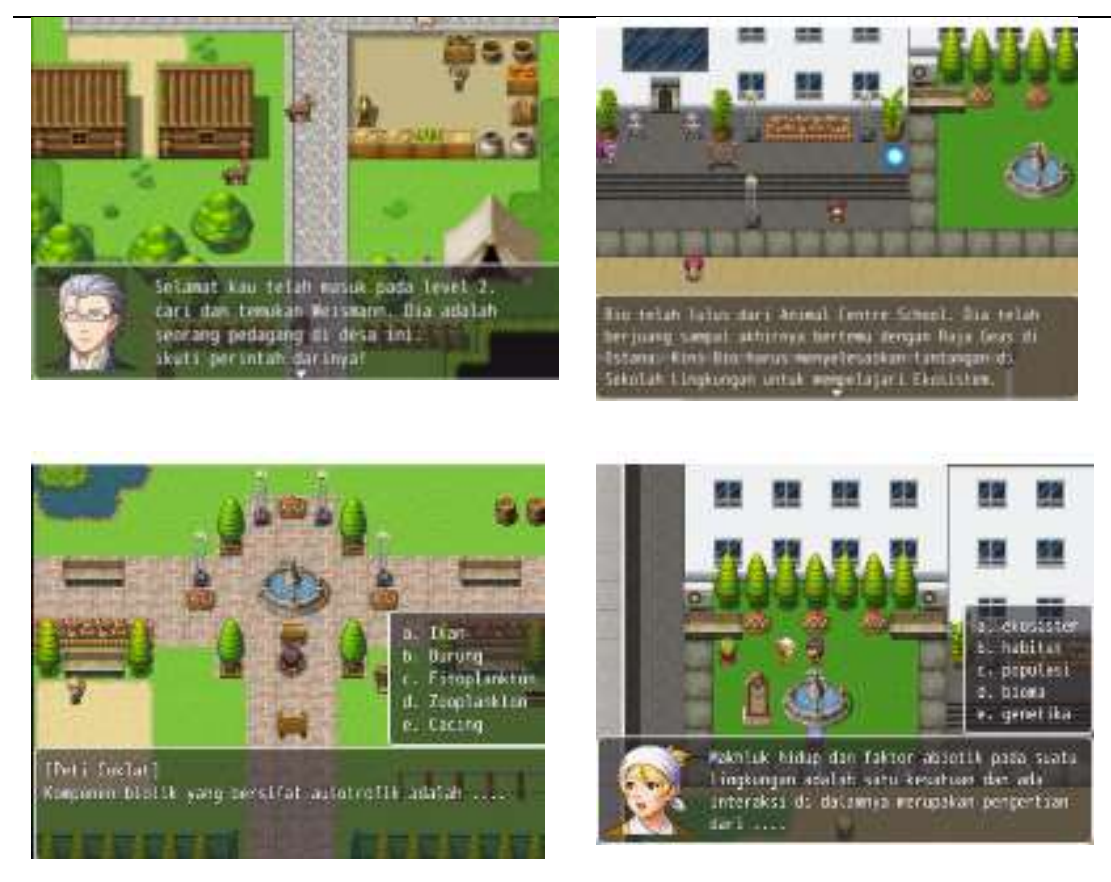

Gambar 1. Tayangan Animasi dan Game

Data respon siswa terhadap penggunaan aplikasi mobile learning berbasis RPG maker MV diperoleh dengan menggunakan angket respon siswa. Adapun persentase respon siswa per indikator ditunjukkan pada tabel 2. 
Tabel. 2 Persentase Respon Siswa Per Indikator

\begin{tabular}{ccccccccl}
\hline \multicolumn{8}{c}{ Persentase Respon Siswa Per indikator } \\
$\mathbf{1}$ & $\mathbf{2}$ & $\mathbf{3}$ & $\mathbf{4}$ & $\mathbf{5}$ & $\mathbf{6}$ & $\mathbf{7}$ & $\mathbf{8}$ & \multicolumn{1}{|}{ Kriteria } \\
\hline 63 & 73.68 & 100 & 63.16 & 100 & 55.3 & 53.9 & 0 & sangat setuju \\
38 & 26.32 & 0 & 34.21 & 0 & 31.6 & 44.7 & 100 & Setuju \\
0 & 0 & 0 & 2.632 & 0 & 10.5 & 1.3 & 0 & kurang setuju \\
0 & 0 & 0 & 0 & 0 & 2.6 & 0 & 0 & tidak setuju \\
\hline
\end{tabular}

Keterangan Indikator Respon Siswa:

1. Respon terhadap pembelajaran Ekositem dengan menggunakan aplikasi mobile learning berbasis RPG maker MV

2. Aktivitas kegiatan belajar

3. Manfaat gambar animasi

4. Efektifitas waktu dalam pembelajaran dengan menggunakan aplikasi mobile learning berbasis RPG maker MV

5. Media dalam pembelajaran biologi

6. Pemahaman materi

7. Kemampuan berpikir kritis siswa

8. Mampu menerapkan dalam kehidupan sehari-hari

Hasil penelitian menunjukkan bahwa pada umumnya siswa memberikan respon positif terhadap kegiatan pembelajaran dengan menggunakan aplikasi mobile learning berbasis RPG maker MV pada materi ekosistem. Hal ini ditunjukkan dari data jumlah siswa yang menyatakan sangat setuju pada tiap item sebesar $70 \%$, setuju sebesar $28,77 \%$, dan kurang setuju sebesar $1,05 \%$. Total skor dari seluruh item respon sebesar 2280, sedangkan total skor tertinggi sebesar 2101. Data tersebut memiliki arti bahwa respon siswa sangat baik terhadap kegiatan pembelajaran dengan menggunakan aplikasi mobile learning berbasis RPG maker MV pada materi ekosistem. Data respon siswa dapat dilihat pada Gambar 2.

\section{Respon Siswa $(\%)$}

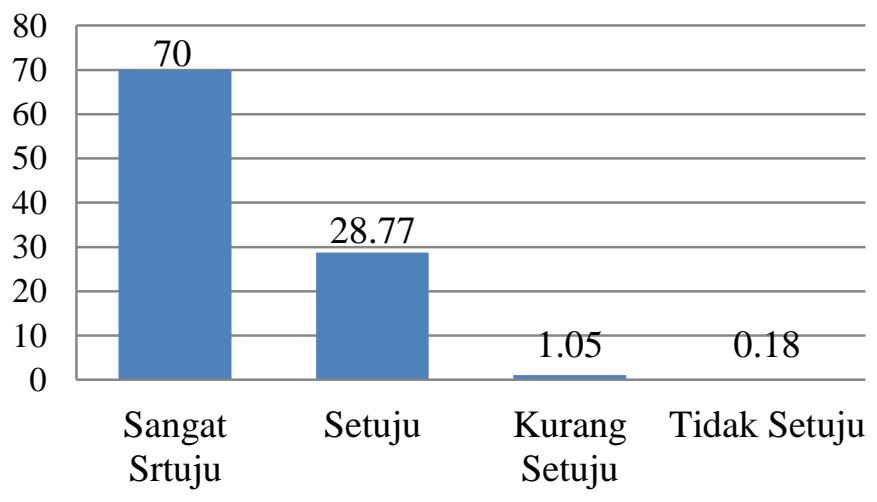

Gambar. 2. Persentase Respon Siswa 
Sebagian besar siswa menyatakan bahwa setelah mengikuti kegiatan pembelajaran dengan menggunakan aplikasi mobile learning berbasis RPG maker MV, mereka merasa termotivasi dalam belajar, suasana kelas menyenangkan, dan lebih memahami materi pelajaran biologi khususnya ekosistem. Sesuai dengan pendapat Prasetyowati (2016) bahwa penggunaan mobile learning dapat memotivasi semangat belajar, suasana kelas menjadi menyenangkan, waktu yang digunakan cukup dan efektif, konsep ekosistem menjadi lebih mudah dikuasai dan diterapkan dalam kehidupan sehari-hari, dan permainan animasi dapat menghilangkan kejenuhan dalam kegiatan belajar mereka.

\section{SIMPULAN}

Simpulan yang diperoleh menunjukkan bahwa keterlaksanaan penerapan aplikasi mobile learning berbasis RPG maker MV dalam pembelajaran ekosistem berada pada kriteria sedang, penerapan aplikasi mobile learning berbasis RPG maker MV dalam pembelajaran ekosistem dapat meningkatkan kemampuan berpikir kritis siswa. Respon siswa juga sangat baik terhadap penggunaan aplikasi mobile learning berbasis RPG maker MV dalam pembelajaran ekosistem.

\section{DAFTAR PUSTAKA}

Alfiana, M. S \& Nurcahyo, H. (2018). Improving Students Learning Motivation Trough Mobile Learning. JPBI (Jurnal Pendidikan Biologi Indonesia), 4 (3), 271-276

Arindra, et al. (2018). I-Invertebrata as an Android Based Learning for Moluscs, Artrhopods, And Echinoderms Identifications and Its Influence on Students Motivations. JPBI (Jurnal Pendidikan Biologi Indonesia), 4 (1), 43-52.

Aripin, I. (2018). Konsep dan Aplikasi Mobile Learning dalam Pembelajaran Biologi. Bio Educatio, 3 (2), 1-9.

Ciampa, K. (2018). Learning in a mobile age: An investigation of student motivation. Journal of Computed Assisted Learning. 30(1), 82-96.

Cresswell, J. (2014). Research Design - Qualitative, Quantitative, \& Mixed Methods Approaches, vol. 4th Ed. SAGE.

Faturahman, A., et al (2018). Penerapan Media Pembelajaran Berbasis Game Android untuk meningkatkan Hasil Belajar Siswa Kelas X MIPA pada Materi Kingdom Animalia. Jurnal Ilmu Alam Indonesia, 2(1), 1-11.

Hack, E. M. A. \& Helwa, H. S. A. (2014). Using digital storytelling and weblogs instruction to enhance EFL narrative writing and critical thinking skills among EFL majors at faculty of education. Internasional Research Journal, 5(1), 8-41. 
Hermawan, D. P et al. (2017) Efektivitas Penggunaan Game Edukasi Berjenis Puzzle, RPG dan Puzzle RPG Sebagai Sarana Belajar Matematika. JUTI: Jurnal Ilmiah Teknologi Informasi, 15(2), 195-205.

Leow, F. T. \& Neo, M. (2014). Interactive Multimedia Learning: Innovating Classroom Education in a Malaysian University. Turkish Online Journal Education Technology, 13(2), 99-110.

Sarrab, M. \& Elgamel, L. (2013). M-Learning and Environment. Internasional Journal Distribution Parallel System, 3(4), 31-38.

Safitri et al. (2018). Students Cognitive Achievment, Critical Thinking Skill, and Metacognitive Awarness in Problem Based Learning. European Journal of Education Studied, 5 (4), 248-258.

Scepanovic, S. (2015). Game Based Mobile Learning-Application Development and Evaluation. The Sixth International Conference on e-Learning, 24-25 September 2015.

Prasetyowati, D. (2016). Efektivitas Mobile Learning pada Mata Kuliah Ditinjau dari Kemampuan Berpikir Kritis Mahasiswa. AKSIOMA, 6(1), no. 1-8.

Weay, A. L \& Masood, M. (2015). The 'Big Picture' of Thematic Multimedia Information Representation in Enhancing Learners' Critical Thinking and History Reasoning. Procedia - Social and Behaviour Science, 197(1), 2058-2065.

Yusuf, M. O. \& Afolabi, A. O. (2010). Effects of computer assisted instruction (CAI) on secondary school students' performance in biology," Turkish Online Journal Education Technology, 9(1), 62-9.

Zubaidah, S. et al. (2018). Revealing the Relationship between Reading Interest and Critical Thinking Skills Trough Remap GI and Remap Jigsaw. International Journal of Instruction, 11 (2), 41-56. 